\title{
Risk Factors of Domestic Violence Reported Before and During the Covid-19 Pandemic: A Systematic Review
}

\author{
Fawwaz Mishbah Syibulhuda ${ }^{1}$ Annastasia Ediati2,** \\ ${ }^{1}$ Fakultas Psikologi, Universitas Diponegoro, Semarang, Indonesia \\ ${ }^{2}$ Fakultas Psikologi, Universitas Diponegoro, Semarang, Indonesia \\ *Corresponding author. Email: ediati@lecturer.undip.ac.id
}

\begin{abstract}
The presence of COVID-19 as a global pandemic has triggered the implementation of several policies such as lockdowns to limit public interactions and controlling the spread of the virus. Meanwhile, pandemic also impacts business and jobs resulted in downsizing and reduced income, leading to increased stress on workers. Stay at home in high tension can easily trigger conflict and domestic violence. The study aims to investigate the risk factors for domestic violence reported before the COVID-19 pandemic and during the pandemic. We performed a systematic literature review on the following databases: Scopus, Science Direct, and ProQuest by using the following keywords: Risk AND Factor AND Domestic AND Violence. From 3965 articles found, we selected 33 articles matched to the inclusion criteria and eligible for review. Our analysis revealed that socioeconomic conditions and mental health are still the risk factors of domestic violence before and during the pandemic. However, no studies reported childhood experiences as a risk factor of domestic violence during the pandemic, though studies before the pandemic highlighted childhood experiences as a risk factor for domestic violence. Reports on risk factors of domestic violence during a pandemic are scarce. Future studies are needed to investigate domestic violence factors during the pandemic to develop an effective prevention program.
\end{abstract}

Keywords: domestic violence, COVID-19 pandemic, risk factor, systematic review.

\section{INTRODUCTION}

Since the enactment of restrictions on community activities or lockdown due to the global pandemic COVID-19, the number of domestic violence cases increased in many countries. More than 4,000 reports related to domestic violence occurred during the pandemic as of April 2020[1]. Not only in the UK, an increasing number of reporters who experienced domestic violence after the lockdown in Singapore (33\%), Cyprus (30\%), France (30\%), and Argentina (25\%) [2]. Some scientists have interpreted the rising domestic violence cases as "pandemics on pandemics." The COVID-19 event as a new phenomenon in the world has impacted people's lives significantly. The essential thing that has become the global discourse is the shaking of world economic conditions.
Low or no income can be a risk factor for domestic violence. Among Pakistani women, low education and early marriage triggered risk factors leading to domestic violence [3]. In general, domestic violence is dominated by collectivism and gender empowerment makes a more significant contribution to actions that are dominated by men rather than women [4]. This situation affirms the tendency of domestic violence to put women as victims. Domestic violence victims have diverse education levels but the majority of victims have an associate degree or equivalent [5]. Having children is a risk factor for physical violence, excessive alcohol consumption, stress, and childhood experiences. Strict parenting and violence behavior in childhood predict domestic violence [6]. 
As the number of domestic violence increased during the COVID-19 pandemic, we assumed that the risk factors of domestic violence during pandemic might be different from domestic violence before the pandemic. This study aims to review reported studies on domestic violence in the last five years, particularly comparing the reported studies before and during the pandemic.

\section{METHOD}

We conducted this systematic review study following the guideline in conducting a systematic review for psychological studies [7] and the PRISMA guidelines [8]. We performed literature searches on September 23-30, 2020 in the following electronic databases: ScienceDirect, ProQuest, and Scopus. We applied the following keywords: Risk AND Factor AND Domestic AND Violence. To obtain relevant articles, we used the following inclusion criteria: 1) Article reporting risk factors for domestic violence before and during COVID-19; 2) original articles (review, case report, book chapter, or else); 3) written in English; 4) full texts are available and accessible; 5) published in years 2015-2020. Figure 1 described the article selection process in detail.

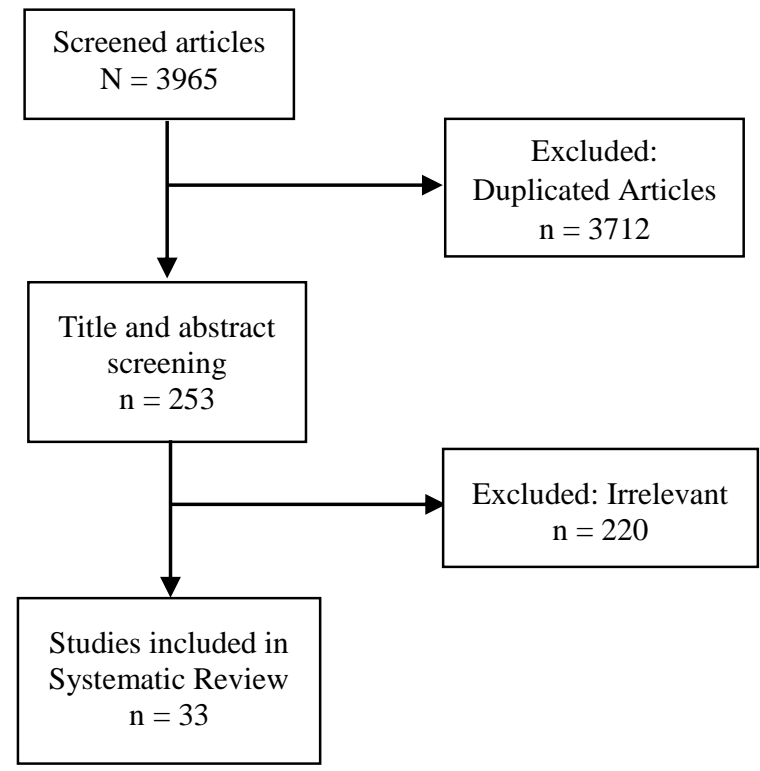

Figure 1. Article selection flowchart

\section{RESULT}

Based on 33 articles for review, we summarized the findings in view of study types, country where the study was conducted, the victims, the perpetrators, risk factors, and the study findings. The summary of the reviewed studies is reported in Table 1.

As reported in Table 1, studies on domestic violence were reported from 32 countries mostly from Asia, Africa, Europe, and America, particularly from Thailand, Turkey, and Nigeria. Based on the demographic distribution, studies on domestic violence were frequently carried out in developing countries. We found that women and children were at risk to be domestic violence victims, while men more frequently reported as perpetrators.

\subsection{Socio-Economic}

In general, studies before the Covid-19 pandemic revealed socio-economic problems as the major cause of women and children at risk for domestic violence [5]. In some countries, social standards that are still closely related to the patriarchal culture have positioned men to always dominate women or groups that tend to be weak [9]. For example, in cases of violence that occur in Nigeria, the culture of polygamy results in a risk of domestic violence perpetrated by husbands against wives and children [10][11]. This is in line with findings from Afghanistan that polygamy has a tendency for wives to be economically dependent on their husbands so that the risk of violence perpetrated by in-laws is greater. Furthermore, this study emphasized the vulnerability of women in marriage including marriage at a young age and polygamy [11]. In Senegal, only marriage is accepted as a type of couple life according to sociology and state religion. There is still forced marriage, a traditional practice for marital life. A forced marriage is a risk factor for domestic violence [12][13].

Studies on domestic violence during the Covid-19 pandemic showed that socio-economic remains the major risk factor of domestic violence. This is in line with previous reports that risk factors in households between March 24 to April 72020 were demographic, socio-economic, and family factors that have been found to be associated with childhood abuse and neglect [14]. Again, financial conditions were a risk factor in the household, especially for children [15].

\subsection{Mental Health}

Previous studies found that mental health is associated with the occurrence of domestic violence. 
Table 1. Data extraction from the reviewed articles

\begin{tabular}{|c|c|c|}
\hline Study [Reference] & Risk Factors & Study Findings \\
\hline $\begin{array}{l}\text { Family type, domestic violence and } \\
\text { under-five mortality in Nigeria [10] }\end{array}$ & $\begin{array}{l}\text { A polygyny family setting makes } \\
\text { women and young children susceptible } \\
\text { to domestic violence. }\end{array}$ & $\begin{array}{l}\text { Family type and domestic violence were } \\
\text { significant predictors of under-five } \\
\text { children mortality in Nigeria }\end{array}$ \\
\hline $\begin{array}{l}\text { Risk and protective factors associated } \\
\text { with domestic abuse among older } \\
\text { Chinese in China [21] }\end{array}$ & $\begin{array}{l}\text { Psychological abuse, physical abuse, } \\
\text { financial exploitation, and caregiver } \\
\text { neglect }\end{array}$ & $\begin{array}{l}\text { The mutually reported rates were } 9.7 \% \text {, } \\
0.8 \% \text {, 33.2\%, and } 39.7 \% \text { for } \\
\text { psychological abuse, physical abuse, } \\
\text { financial exploitation, and caregiver } \\
\text { neglect respectively. }\end{array}$ \\
\hline $\begin{array}{l}\text { Family background in upbringing } \\
\text { experience of violence, and authority } \\
\text { relationship among Married Thai } \\
\text { Muslims Couples in Pattani Province } \\
\text { experiencing domestic violence [6] }\end{array}$ & $\begin{array}{l}\text { Strict upbringing, violent behavior in } \\
\text { childhood, witnessing parents } \\
\text { quarreling in childhood, and violent } \\
\text { behavior in childhood were risk factors } \\
\text { for domestic violence }\end{array}$ & $\begin{array}{l}\text { Family background associated with } \\
\text { domestic violence. }\end{array}$ \\
\hline $\begin{array}{l}\text { The specific and combined role of } \\
\text { domestic violence and mental health } \\
\text { disorders during pregnancy on } \\
\text { newborn health [22] }\end{array}$ & $\begin{array}{l}\text { A poor nutritional status at birth highly } \\
\text { correlated with poverty and mental } \\
\text { health disorder }\end{array}$ & $\begin{array}{l}\text { Domestic violence and mental disorders } \\
\text { were highly correlated. }\end{array}$ \\
\hline $\begin{array}{l}\text { Domestic violence among married } \\
\text { women of reproductive age in } \\
\text { Zimbabwe [23] }\end{array}$ & $\begin{array}{l}\text { Risk of domestic violence was higher } \\
\text { among working women than } \\
\text { unemployed women. }\end{array}$ & $\begin{array}{l}\text { Women, either workers or unemployed, } \\
\text { were at risk for domestic violence }\end{array}$ \\
\hline $\begin{array}{l}\text { Domestic violence and perinatal } \\
\text { outcomes: A prospective cohort study } \\
\text { from Nepal [24] }\end{array}$ & $\begin{array}{l}\text { Domestic violence a potential risk } \\
\text { factor for severe morbidity and } \\
\text { mortality in newborns. }\end{array}$ & $\begin{array}{l}\text { Exposure to any domestic violence } \\
\text { during pregnancy did not associated } \\
\text { with risk of a low birthweight baby or } \\
\text { birth by cesarean section }\end{array}$ \\
\hline $\begin{array}{l}\text { Domestic violence and its associated } \\
\text { factors among married women of a } \\
\text { village development committee of } \\
\text { rural Nepal [25] }\end{array}$ & Mental health & $\begin{array}{l}\text { The lifetime domestic violence rate was } \\
38.6 \% \text {; In the past } 1 \text { year, the prevalence } \\
\text { was } 23.1 \% \text {. Approx. } 12.4 \% \text { of women } \\
\text { experienced all forms of violence } \\
\text { concurrently. }\end{array}$ \\
\hline $\begin{array}{l}\text { Violence against women: prevalence } \\
\text { and risk factors in Turkish [26] }\end{array}$ & $\begin{array}{l}\text { One of the most important risk factors } \\
\text { for violence against women is the low } \\
\text { educational level of women }\end{array}$ & $\begin{array}{l}\text { Age, education, employment status, } \\
\text { social insurance, immigration status, } \\
\text { place of residence, marital age, year of } \\
\text { marriage of women; age, education } \\
\text { status, and employment were associated } \\
\text { with violence against women. }\end{array}$ \\
\hline $\begin{array}{l}\text { Domestic violence as a risk factor for } \\
\text { postpartum depression among } \\
\text { Ethiopian women: Facility based study } \\
{[16]}\end{array}$ & Mental health & $\begin{array}{l}\text { About } 23.3 \% \text { of the women had the } \\
\text { symptom of postpartum depression. }\end{array}$ \\
\hline $\begin{array}{l}\text { Domestic violence victims in a } \\
\text { hospital setting: Prevalence, health } \\
\text { impact and patients' preferences [27] }\end{array}$ & $\begin{array}{l}\text { Childhood abuse was a significant risk } \\
\text { factor for DV and mental health }\end{array}$ & $\begin{array}{l}\text { Lifetime DV exposure was associated } \\
\text { with a significant risk for both physical } \\
\text { and mental health-problems. }\end{array}$ \\
\hline $\begin{array}{l}\text { Domestic violence against women as a } \\
\text { risk factor for depressive and anxiety } \\
\text { disorders: Findings from domestic } \\
\text { violence household survey in Tehran, } \\
\text { Iran [17] }\end{array}$ & $\begin{array}{l}\text { Domestic violence against women is a } \\
\text { significant social risk factor for not } \\
\text { only depression and anxiety as research } \\
\text { found in this study but also other types } \\
\text { of physical and mental health problems } \\
\text { in a wider view }\end{array}$ & $\begin{array}{l}\text { DV as a social factor is significantly } \\
\text { correlated factor with depression and } \\
\text { anxiety, }\end{array}$ \\
\hline $\begin{array}{l}\text { Prevalence and risk factors of } \\
\text { domestic violence in women attending }\end{array}$ & $\begin{array}{l}\text { Risk factors for being a victim of abuse } \\
\text { include being single or divorced, }\end{array}$ & $\begin{array}{l}\text { Risk factors for being a victim of abuse } \\
\text { include being single or divorced, having }\end{array}$ \\
\hline
\end{tabular}




\begin{tabular}{|c|c|c|}
\hline $\begin{array}{l}\text { the National Guard Primary Health } \\
\text { Care Centers in the Western Region, } \\
\text { Saudi Arabia } 2018 \text { [28] }\end{array}$ & $\begin{array}{l}\text { having a postgraduate level of } \\
\text { education, employed, and being } \\
\text { financially independent of the husband. }\end{array}$ & $\begin{array}{l}\text { a postgraduate level of education, } \\
\text { employed, and being financially } \\
\text { independent of the husband. }\end{array}$ \\
\hline $\begin{array}{l}725 \text { Domestic violence and risk factors } \\
\text { among rural and urban pregnant } \\
\text { women in Niger-Delta, Nigeria [29] }\end{array}$ & $\begin{array}{l}\text { The risk factors were geographic } \\
\text { location that is residing in a rural area. } \\
\text { alcohol use by victims; alcohol and } \\
\text { other substance abuse and controlling } \\
\text { behavior by intimate partners. }\end{array}$ & $\begin{array}{l}\text { The prevalence of domestic violence } \\
\text { against pregnant women was high } \\
\text { among pregnant women in rural and } \\
\text { urban areas }\end{array}$ \\
\hline $\begin{array}{l}\text { Overcrowding as a risk factor for } \\
\text { domestic violence and antisocial } \\
\text { behaviour among adolescents in } \\
\text { Ejigbo, Lagos, Nigeria [30] }\end{array}$ & $\begin{array}{l}\text { Overcrowding showed significant } \\
\text { associations with four of five scales } \\
\text { measuring aggressive and antisocial } \\
\text { behavior. }\end{array}$ & $\begin{array}{l}\text { Level of poverty as correlated to four of } \\
\text { five scales measuring aggressive and } \\
\text { antisocial behavior. }\end{array}$ \\
\hline $\begin{array}{l}\text { Shared risk factors for the perpetration } \\
\text { of physical dating violence, bullying, } \\
\text { and sexual harassment among } \\
\text { adolescents exposed to domestic } \\
\text { violence [31] }\end{array}$ & $\begin{array}{l}\text { The significant risk factors that were } \\
\text { shared across all three forms of } \\
\text { aggression were acceptance of sexual } \\
\text { violence, mother-adolescent discord, } \\
\text { family conflict low maternal } \\
\text { monitoring low mother-adolescent } \\
\text { closeness, low family cohesion, } \\
\text { depressed affect, feelings of anger, and } \\
\text { anger reactivity. }\end{array}$ & $\begin{array}{l}\text { Affect, and anger reactivity were risk } \\
\text { factors that were shared by the three } \\
\text { forms of aggression and that mother- } \\
\text { adolescent discord and adolescent } \\
\text { acceptance of sexual violence wereas } \\
\text { marginally associated with all three } \\
\text { forms of aggression. }\end{array}$ \\
\hline $\begin{array}{l}\text { Determinants of domestic violence } \\
\text { against women in Ghana [32] }\end{array}$ & $\begin{array}{l}\text { The risk of ever experiencing domestic } \\
\text { violence was } 48 \% \text { less likely for } \\
\text { women whose husbands had higher } \\
\text { than secondary education as compared } \\
\text { to women whose husbands never had } \\
\text { any formal education. }\end{array}$ & $\begin{array}{l}\text { Place of residence, alcohol use by } \\
\text { husband and family history of violence } \\
\text { do increase a woman's risk of ever } \\
\text { experiencing domestic violence. }\end{array}$ \\
\hline $\begin{array}{l}\text { Prevalence and risk factors of domestic } \\
\text { violence and its impacts on women's } \\
\text { mental health in Gilgit-Baltistan, } \\
\text { Pakistan [19] }\end{array}$ & $\begin{array}{l}\text { Poverty, the influence of in-laws, } \\
\text { second marriage, stepchildren, forceful } \\
\text { intimate relationships, husband's } \\
\text { irresponsibility, and addiction, and } \\
\text { handicapped children. }\end{array}$ & $\begin{array}{l}\text { A higher level of domestic violence, } \\
\text { associated risk factors, and poor mental } \\
\text { health of abused women in GB. }\end{array}$ \\
\hline $\begin{array}{l}\text { Prevalence and incidence of domestic } \\
\text { violence during pregnancy and } \\
\text { associated risk factors: A study from } \\
\text { the South of Sweden [33] }\end{array}$ & $\begin{array}{l}\text { Being single/living apart, having a } \\
\text { long- term problem with sleeping } \\
\text { and/or having several symptoms of } \\
\text { depression during pregnancy }\end{array}$ & $\begin{array}{l}\text { Further, this is important knowledge for } \\
\text { health care providers to develop or } \\
\text { upgrade guidelines and plans of action } \\
\text { for pregnant women exposed to violence }\end{array}$ \\
\hline $\begin{array}{l}\text { Prevalence of domestic violence } \\
\text { against married women in Turkey and } \\
\text { associated risk factors [34] }\end{array}$ & $\begin{array}{l}\text { Being discontent in marriage, living in } \\
\text { a family in which children are abused, } \\
\text { not contributing to decision making at } \\
\text { home, living in a large family and } \\
\text { living in Kars. }\end{array}$ & $\begin{array}{l}\text { The determined risk factors related to } \\
\text { violence were discontent in marriage, } \\
\text { children abuse at home, not participating } \\
\text { in decision-taking at home, living in the } \\
\text { province of Kars and living in a large } \\
\text { family }\end{array}$ \\
\hline $\begin{array}{l}\text { Violence against Afghan women by } \\
\text { husbands, mothers-in-law and } \\
\text { siblings-in-law/siblings: Risk markers } \\
\text { and health consequences [11] }\end{array}$ & $\begin{array}{l}\text { Economic vulnerability and } \\
\text { dependency of women as a risk factor } \\
\text { for in-law violence, specifically in } \\
\text { communities that are highly dependent } \\
\text { on remittances from migrant workers }\end{array}$ & $\begin{array}{l}\text { Physical violence was associated with } \\
\text { food insecurity and having to borrow for } \\
\text { food, being in a polygamous marriage, } \\
\text { living with their mother-in-law }\end{array}$ \\
\hline $\begin{array}{l}\text { Factors affecting domestic violence } \\
\text { risk behaviors among Thai Muslim } \\
\text { married couples in Satun province [35] }\end{array}$ & $\begin{array}{l}\text { Factors affecting domestic risk } \\
\text { behaviors, namely jealous wives, } \\
\text { suspicious wives, drinking husbands, } \\
\text { drug abusive husbands, being not ready } \\
\text { to have one's own family, and lack of } \\
\text { time for discussions. }\end{array}$ & $\begin{array}{l}\text { Risk behaviors, namely jealous wives, } \\
\text { suspicious wives, drinking husbands, } \\
\text { drug abusive husbands, being not ready } \\
\text { to have one's own family, and lack of } \\
\text { time for discussions. }\end{array}$ \\
\hline Domestic violence in Dakar [12] & Young age is a risk factor for spousal & Economic abuse in the past 12 months \\
\hline
\end{tabular}




\begin{tabular}{|c|c|c|}
\hline & $\begin{array}{l}\text { violence. Forced marriage is a risk } \\
\text { factor for domestic violence }\end{array}$ & $\begin{array}{l}\text { was } 52 \text { reported by } 48 \text { respondents, or } \\
33.33 \% \text { of the spousal violence victim } \\
53 \text { population. }\end{array}$ \\
\hline $\begin{array}{l}\text { Factors Predicting domestic violence } \\
\text { among Thai Muslim married couples } \\
\text { in Pattani province_[5] }\end{array}$ & $\begin{array}{l}\text { Strict upbringing, violent behavior in } \\
\text { childhood, and females' inferior status } \\
\text { while severe punishment in childhood. }\end{array}$ & $\begin{array}{l}\text { Three predictors were found to have } \\
\text { positive relationships with domestic } \\
\text { violence: strict upbringing, violent } \\
\text { behavior in childhood }\end{array}$ \\
\hline $\begin{array}{l}\text { Factors related to domestic_violence in } \\
\text { pregnant women [36] }\end{array}$ & $\begin{array}{l}\text { Academic qualifications } 9 \text { years and } \\
\text { unemployed } 1000 \text { euros monthly } \\
\text { income and good agglomeration index } \\
\text { planned pregnancy but not monitored. }\end{array}$ & $\begin{array}{l}\text { Significant result of academic } \\
\text { qualifications } 9 \text { years and unemployed, } \\
1000 \text { euros monthly income, and good } \\
\text { agglomeration, planned, and pregnancy }\end{array}$ \\
\hline $\begin{array}{l}\text { Data-informed recommendations for } \\
\text { services providers working with } \\
\text { vulnerable children and families } \\
\text { during the COVID-19 pandemic [15] }\end{array}$ & $\begin{array}{l}\text { Not having access to vital services. The } \\
\text { NGOs experienced government } \\
\text { restrictions, decreased financial } \\
\text { support, and the inability to adequately } \\
\text { provide services. }\end{array}$ & $\begin{array}{l}\text { The NGOs experienced government } \\
\text { restrictions, decreased financial support, } \\
\text { and inability to adequately provide } \\
\text { services. Increased }\end{array}$ \\
\hline $\begin{array}{l}\text { Prevalence of domestic violence and } \\
\text { its association with family factors: A } \\
\text { cross-sectional study among pregnant } \\
\text { women in urban communities of } \\
\text { Hengyang City, China [37] }\end{array}$ & $\begin{array}{l}\text { Risk factors for DV were tensions with } \\
\text { their mother-in-law, tensions with other } \\
\text { family members, medium household } \\
\text { debt, middle and low family }\end{array}$ & $\begin{array}{l}\text { In summary, women in late pregnancy } \\
\text { were at higher risk of DV in the family } \\
\text { with tensions, medium household debt } \\
\text { and family dysfunction }\end{array}$ \\
\hline $\begin{array}{l}\text { Domestic violence against women in } \\
\text { Turkey [9] }\end{array}$ & $\begin{array}{l}\text { Family integrity is impaired and } \\
\text { disagreements are more frequent, } \\
\text { affecting the level of domestic } \\
\text { violence. }\end{array}$ & $\begin{array}{l}\text { Low social status in Turkey was } \\
\text { connected to the level of domestic } \\
\text { violence. }\end{array}$ \\
\hline $\begin{array}{l}\text { The effect of university students' } \\
\text { violence tendency on their attitude } \\
\text { towards domestic violence and the } \\
\text { factors affecting domestic violence } \\
\text { attitudes [38] }\end{array}$ & $\begin{array}{l}\text { Various factors including biological, } \\
\text { psychological, social, cultural, } \\
\text { economic and political ones may affect } \\
\text { the formation of violence }\end{array}$ & $\begin{array}{l}\text { Young people's exposure to violence } \\
\text { was found high }(42.8 \%) \text {. Nevertheless, } \\
\text { their scores on violence tendencies and } \\
\text { domestic violence attitude were } \\
\text { ascertained low. }\end{array}$ \\
\hline $\begin{array}{l}\text { Prevalence of spousal violence and } \\
\text { associated risk factors: Facts from } \\
\text { Pakistan Demographics and Health } \\
\text { Survey 2012-13 [39] }\end{array}$ & $\begin{array}{l}\text { Education and working status of } \\
\text { women and their husband, ethnicity } \\
\text { and wealth index affecting the } \\
\text { prevalence of spousal violence }\end{array}$ & $\begin{array}{l}\text { Education, profession, ethnicity and } \\
\text { wealth index are found significant risk } \\
\text { factors associated with spousal violence. }\end{array}$ \\
\hline $\begin{array}{l}\text { Changes and socioeconomic factors } \\
\text { associated with attitudes towards } \\
\text { domestic violence among Vietnamese } \\
\text { women aged 15-49: [13] }\end{array}$ & $\begin{array}{l}\text { Socioeconomic factors associated with } \\
\text { women's condoning of domestic } \\
\text { violence were age, wealth, education } \\
\text { level, and living area. }\end{array}$ & $\begin{array}{l}\text { Higher educational attainment in women } \\
\text { is an important predictor of women's } \\
\text { attitudes toward domestic violence. }\end{array}$ \\
\hline $\begin{array}{l}\text { Domestic violence and its } \\
\text { determinants among 15-49-year-old } \\
\text { women in a rural block in South India } \\
{[18]}\end{array}$ & $\begin{array}{l}\text { Socio-economic, well-being, physical } \\
\text { and mental health of a woman, her } \\
\text { family, and thereby, society as a whole. }\end{array}$ & $\begin{array}{l}\text { Alcohol consumption by husband, } \\
\text { controlling behavior by family member, } \\
\text { and woman's employment were } \\
\text { statistically significant determinants of } \\
\text { domestic violence. }\end{array}$ \\
\hline $\begin{array}{l}\text { Immediate impact of stay-at-home } \\
\text { orders to control COVID-19 } \\
\text { transmission on socioeconomic } \\
\text { conditions, food insecurity, mental } \\
\text { health, and intimate partner violence in } \\
\text { Bangladeshi women and their families } \\
\text { [20] }\end{array}$ & - & $\begin{array}{l}\text { Median monthly family income fell } \\
\text { from US } \$ 212 \text { at baseline to } \$ 59 \text { during } \\
\text { lockdown; food insecurity, respectively, } \\
\text { depression and anxiety symptoms } \\
\text { increased during the lockdown. }\end{array}$ \\
\hline
\end{tabular}


For example, persons with a postpartum depressive disorder in Ethiopia $23.3 \%$ of 144 participants experienced domestic violence [16]. Likewise, domestic violence has a significant presence with depression victims and casualties [17]. Based previous study from Sweden, mental health disorders such as depression, sleep problems, feeling alone were common reported among pregnant women who experienced domestic violence [18]. This led to findings for higher rates of domestic violence, associated risk factors, and poor mental health of women who were abused in GB [19]. This is in line with findings from Southern India that domestic violence has hidden implications for the socioeconomic well-being, the physical and mental health of women, their families, and society as a whole [18].

During the COVID-19 pandemic, not only socioeconomic, neglect and childhood violence were also risk factors for domestic violence [14]. In Bangladesh, between 19 May and 18 June 2020, lockdowns had an adverse impact on the mental health of mothers and children who were victims of domestic violence [20]. This shows that mental health is a risk factor that needs to be considered in dealing with COVID-19 pandemic.

\subsection{Conclusion}

The COVID-19 pandemic brought lots of tension and pressures into the families. Questions were raised whether domestic violence will increase during the pandemic or will there be different pattern of risk factors related to domestic violence reported before pandemic and during the pandemic. These questions led us to conduct the study. Our analysis revealed that socioeconomic conditions and mental health are still the risk factors of domestic violence before and during the pandemic. However, no studies reported childhood experiences as a risk factor of domestic violence during the pandemic, though studies before the pandemic highlighted childhood experiences as a risk factor for domestic violence. Reports on risk factors of domestic violence during a pandemic are scarce. Future studies are needed to investigate domestic violence factors during the pandemic to develop an effective prevention program.

\section{AUTHORS' CONTRIBUTIONS}

FMS involved in study design, literature search, data analysis, and drafting the manuscript. AE involved in study design, data analysis, drafting and finalizing the manuscript.

\section{ACKNOWLEDGMENTS}

We would like to thank the Fakultas Psikologi, Universitas Diponegoro for partially funded the study. We declare no conflict of interest.

\section{REFERENCES}

[1] T. Snuggs. Coronavirus: 4,000 domestic abuse arrests in London in just six weeks, police say | UK News | Sky News. Sky News, Apr. 24, 2020. Available from: https://news.sky.com/story/coronavirus-4-000domestic-abuse-arrests-in-london-in-just-sixweeks-police-say-11978358 (accessed Jan. 04, 2021).

[2] UN Women. Issue brief: COVID-19 and ending violence against women and girls | Digital library: Publications | UN Women - Headquarters. Available from https://www.unwomen.org/en/digitallibrary/publications/2020/04/issue-brief-covid-19and-ending-violence-against-women-and-girls (accessed Jan. 04, 2021).

[3] M. Nasrullah, R. Zakar, M. Z. Zakar, S. Abbas, and R. Safdar. Circumstances leading to intimate partner violence against women married as children: A qualitative study in Urban Slums of Lahore, Pakistan. BMC Int Health Hum Rights 15(23) (2015) 1-7 DOI: 10.1186/s12914-0150060-0.

[4] K. K. Lacey, C. M. West, N. Matusko, and J. S. Jackson. Prevalence and factors associated with severe physical intimate partner violence among U.S. Black Women: A comparison of African American and Caribbean Blacks. Violence Against Women. 22(6) (2016) 651-670 DOI: $10.1177 / 1077801215610014$

[5] K. Laeheem and K. Boonprakarn. Factors predicting domestic violence among Thai Muslim married couples in Pattani province. Kasetsart J. Soc. Sci. 38(3) (2017) 352-358 DOI: 10.1016/j.kjss.2016.10.005.

[6] K. Laeheem and K. Boonprakarn, "Family background in upbringing, experience of violence, and authority relationship among married, Thai, Muslim couples in Pattani province experiencing domestic violence. Kasetsart J. Soc. Sci. 37(2) (2016) 93-99 DOI: 10.1016/j.kjss.2015.12.001.

[7] L. de F. Carvalho, G. Pianowski, and M. A. dos Santos, "Guidelines for conducting and publishing systematic reviews in psychology," Estudos de Psicologia (Campinas) 36 (2019) DOI: 10.1590/1982-0275201936e180144. 
[8] D. Moher, A. Liberati, J. Tetzlaff, D. G. Altman. "Preferred reporting items for systematic reviews and meta-analyses: The PRISMA statement. PLoS Med. 6(7) 2009 DOI: 10.1371/journal.pmed.1000097.

[9] F. Basar, N. Demirci. Domestic violence against women in Turkey. Pak J Med Sci. 34(3) (2018) 660-665 DOI: 10.12669/pjms.343.15139.

[10] A. Titilayo, O. O. Anuodo, and M. E. Palamuleni, Family type, domestic violence and under-five mortality in Nigeria. Afr Health Sci. 17(2) (2017) 538-548 DOI: 10.4314/ahs.v17i2.30.

[11] R. Jewkes, J. Corboz, and A. Gibbs. Violence against Afghan women by husbands, mothers-inlaw and siblings-in-law/siblings: Risk markers and health consequences in an analysis of the baseline of a randomised controlled trial. PLOS ONE. 14(2) (2019) e0211361 DOI: 10.1371/journal.pone.0211361.

[12] M. M. Soumah, O. Diop. Domestic violence in Dakar. Forensic Sci. Int. 2 (2020) DOI: 10.1016/j.fsir.2020.100109.

[13] O.T.H.Trinh, J.Oh, S.Choi, K.G.To, D.V.Do. Global health action changes and socioeconomic factors associated with attitudes towards domestic violence among Vietnamese women aged 15-49: findings from the Multiple Indicator Cluster Surveys, 2006-2011. Glob. Health Action 9(1) (2016) DOI: 10.3402/gha.v9.29577.

[14] A. M. Jarnecke, J. C. Flanagan. Staying safe during COVID-19: How a pandemic can escalate risk for intimate partner violence and what can be done to provide individuals with resources and support. Psychol Trauma 12(S1) (2020) S202S204, DOI: $10.1037 / \operatorname{tra0000688.~}$

[15] N. G. Wilke, A. H. Howard, D. Pop, Datainformed recommendations for services providers working with vulnerable children and families during the COVID-19 pandemic. Child Abuse Negl 110(2) (2020) DOI: 10.1016/j.chiabu.2020.104642.

[16] A. F. Adamu, Y. M. Adinew. Domestic violence as a risk factor for postpartum depression among Ethiopian women: Facility based study. Clin Pract Epidemiol Ment Health 14(1) (2018) 109-119 DOI: $10.2174 / 1745017901814010109$.

[17] M. Ahmadzad-Asl, F. Davoudi, N. Zarei, H. Mohammad-Sadeghi, M. Rasoulian. Domestic violence against women as a risk factor for depressive and anxiety disorders: Findings from domestic violence household survey in Tehran, Iran. Arch Womens Ment Health. 19(5) (2016) 861-869 DOI: 10.1007/s00737-016-0626-4.
[18] A. Ram, C. Victor, H. Christy, S. Hembrom, A Cherian, V. Mohan, Domestic violence and its determinants among 15-49-year-old women in a rural block in South India. Indian J Community Med. 44(4) (2019) 362-367 DOI: 10.4103/ijcm.IJCM_84_19.

[19] H. Hussain, S. Hussain, S. Zahra, T. Hussain, Prevalence and risk factors of domestic violence and its impacts on women's mental health in Gilgit-Baltistan, Pakistan. Pakistan J Med. Sci. 36(4) (2020) 627-631 DOI: 10.12669/pjms.36.4.1530.

[20] J. D. Hamadani et al., Immediate impact of stay-athome orders to control COVID-19 transmission on socioeconomic conditions, food insecurity, mental health, and intimate partner violence in Bangladeshi women and their families: An interrupted time series. Lancet Glob Health 8(11) (2020) e1380-e1389 DOI: $10.1016 / \mathrm{S} 2214$ 109X(20)30366-1.

[21] B. Fang, E. Yan, D. W. L. Lai. Risk and protective factors associated with domestic abuse among older Chinese in the People's Republic of China. Arch Gerontol Geriatr 82 (2019) 120-127 DOI: 10.1016/j.archger.2019.02.001.

[22] A. A. Ferraro et al. The specific and combined role of domestic violence and mental health disorders during pregnancy on new-born health. BMC Pregnancy Childbirth 17(1) DOI: 10.1186/s12884017-1438-X.

[23] J. Lasong et al. Domestic violence among married women of reproductive age in Zimbabwe: A cross sectional study. BMC Public Health 20(354) (2020) 1-11 DOI: 10.1186/s12889-020-8447-9.

[24] K. D. Pun et al. Domestic violence and perinatal outcomes - A prospective cohort study from Nepal. BMC Public Health 19(671) (2019) DOI: 10.1186/s12889-019-6967-y.

[25] D. Sapkota, S. Bhattarai, D. Baral, and P. K. Pokharel. Domestic violence and its associated factors among married women of a village development committee of rural Nepal. BMC Res Notes 9(178) (2016) DOI: 10.1186/s13104-0161986-6.

[26] S. Sen, N. Bolsoy. Violence against women: Prevalence and risk factors in Turkish sample. BMC Womens Health 17(100) (2017) DOI: 10.1186/s12905-017-0454-3.

[27] D. Riedl et al.. Domestic violence victims in a hospital setting: Prevalence, health impact and patients' preferences-results from a cross-sectional study. Eur J Psychotraumatol 10(1) (2019) 1-11 DOI: $10.1080 / 20008198.2019 .1654063$. 
[28] R. Wali, A. Khalil, R. Alattas, R. Foudah, I. Meftah, S. Sarhan. Prevalence and risk factors of domestic violence in women attending the National Guard Primary Health Care Centers in the Western Region, Saudi Arabia, 2018. BMC Public Health 20(239) (2020) DOI: 10.1186/s12889-0208156-4.

[29] O. Tella, C. Tobin-west, S. Babatunde. 725 Domestic violence and risk factors among rural and urban pregnant women in Niger-Delta, Nigeria. Inj. Prev. 22 (2016) DOI: 10.1136/injuryprev-2016-042156.725.

[30] O. Makinde, K. Björkqvist, K. Österman. Overcrowding as a risk factor for domestic violence and antisocial behaviour among adolescents in Ejigbo, Lagos, Nigeria. Glob Ment Health 3 (2016) e16 DOI: 10.1017/gmh.2016.10.

[31] V. A. Foshee et al.. Shared risk factors for the perpetration of physical dating violence, bullying, and sexual harassment among adolescents exposed to domestic violence. J. Youth Adolesc. 45(4) (2016) 672-686 DOI: 10.1007/s10964-015-0404$\mathrm{z}$.

[32] E. S. O. Adjah, I. Agbemafle, Determinants of domestic violence against women in Ghana. BMC Public Health 16(368) (2016) DOI: 10.1186/s12889-016-3041-x.

[33] H. Finnbogadóttir, A. K. Dykes, C. Wann-Hansson. Prevalence and incidence of domestic violence during pregnancy and associated risk factors: A longitudinal cohort study in the south of Sweden. BMC Pregnancy Childbirth 16(228) (2016) DOI: 10.1186/s12884-016-1017-6.

[34] G. Tanriverdi, C. Çapik, M. Y. Gürsoy. Prevalence of domestic violence against married women in Turkey and associated risk factors. Turkiye Klinikleri J Med. Sci. 38(3) (2018) 218-229 DOI: 10.5336/medsci.2017-58822.

[35] K. Laeheem. Factors affecting domestic violence risk behaviors among Thai Muslim married couples in Satun province. Kasetsart J Soc.Sci. 37(3) (2016) 182-189 DOI: 10.1016/j.kjss.2016.08.008.

[36] E. Coutinho, F. Almeida, J. Duarte, C. Chaves, P. Nelas, O. Amaral. Factors related to domestic violence in pregnant women. Procedia Soc Behavs Sci. $171 \quad$ (2015) 1280-1287 DOI: 10.1016/j.sbspro.2015.01.242.

[37] B. Zheng et al. The prevalence of domestic violence and its association with family factors: A cross-sectional study among pregnant women in urban communities of Hengyang City, China. BMC Public Health 20(620) (2020) DOI: 10.1186/s12889-020-08683-9.
[38] R. Yagiz, Ü. Sevil, and Ö. Guner. The effect of university students' violence tendency on their attitude towards domestic violence and the factors affecting domestic violence attitudes. J Inj Violence Res. 12(1) (2020) 39-46 DOI: 10.5249/jivr.v12i1.1224.

[39] S. Hussain, M. Usman, M. Sabir, R. Zakar, A. Usman. Prevalence of spousal violence and associated risk factors: Facts from Pakistan demographics and health survey 2012-13. J. Fam. Violence 32(7) (2017) 711-719 DOI: 10.1007/s10896-017-9915-6. 